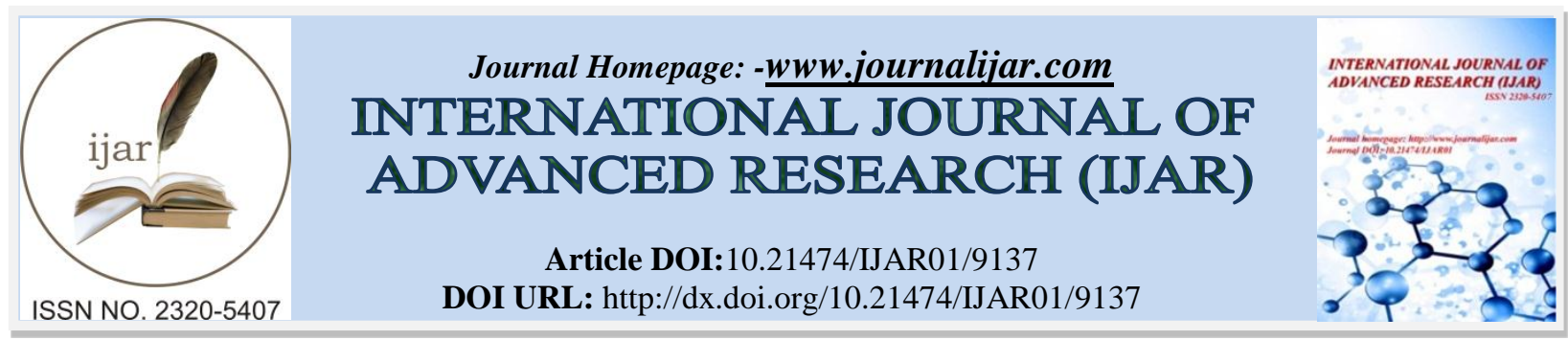

RESEARCH ARTICLE

\title{
LIFESTYLE DISORDER WITH ITS CORRELATION TO AGNI DUSHTI AS CORE AETIOLOGICAL INTERVENTION- A CONCISE REVIEW.
}

\section{Dr.Sunita Temhunna ${ }^{1}$,Dr.Sangram Mishra ${ }^{2}$ and Dr.Nalinikant Parida ${ }^{3}$.}

1. Assistant Professor, Dept. of Samhita siddhant, Rajiv lochan ayurvedic medical college, Durg (C.G.).

2. Professor and H.O.D. Dept. of Samhita siddhant, Govt.model ayurvedic medical college, Kolawada,Gujrat.

3. Assistant Professor, Dept. of Dravya Guna, Rajiv lochan ayurvedic medical college, Durg (C.G.).

\section{Manuscript Info}

\section{Manuscript History}

Received: 24 March 2019

Final Accepted: 26 April 2019

Published: May 2019

Key words:-

words;lifestyle,panchkarma.

\begin{abstract}
Lifestyle is a distinguishing (typical or personal) group of behaviors adopted by a person which includes one's habits, customs, social group, mode of dress, general diet, kinds of entertainment, language characteristics and the manner in which one performs common daily activities of living. So, lifestyle is often an accurate reflection of our deepest values, attitudes, prejudices, moral standards, economic approach and personal philosophy. The most common Lifestyle diseases include hypertension, Diabetes Mellitus, Arthritis, Obesity, Insomnia etc. which are the major cause of mortality in today's world. The incidence of lifestyle diseases like hypertension, diabetes mellitus, dyslipidemia and overweight/obesity associated with cardiovascular diseases is high on the rise. Cardio-vascular disorders continue to be the major cause of mortality representing about $30 \%$ of all deaths worldwide. With rapid economic development and increasing westernization of lifestyle in the past few decades, prevalence of these diseases has reached alarming proportions among Indians in the recent years. As Ayurveda is recognized as foremost life science and describes ways to prevent and manage lifestyle disorders, the world is being attracted towards its potential. Ayurveda provides better solution in the forms of proper dietary management, lifestyle advises, Panchakarma like detoxification and bio-purification procedures, medicaments, and rejuvenation therapies. The holistic approach of Ayurveda, treating the patient as a whole, meaning intervention targeted towards complete physical, psychological, and spiritual well-being makes this science a wonderful option in lifestyle disorders.
\end{abstract}

Copy Right, IJAR, 2019,. All rights reserved.

\section{Introduction:-}

In India with increasing prevalence of life-style diseases, one out of four Indians is at risk of dying from noncommunicable diseases like diabetes, cardio-vascular ailments or cancer before the age of 70, according to estimates of various global and domestic organizations. According to the NCD (Non Communicable Disease) country profiles of 2014 released by WHO, diseases like cancer, chronic respiratory problems and cardiovascular diseases are the biggest global killers accounting for 38 million deaths every year with a whopping 28 million in low and middle -

Corresponding Author:-Dr.Sunita Temhunna.

Address:-Assistant Professor, Dept. of Samhita siddhant, Rajiv lochan ayurvedic medical college, Durg (C.G.). 
income countries, including India. In India as per WHO estimates, NCDs account for almost $60 \%$ of the total mortality reported annually in India.

Life style disorders and its correlation with pathya apathy and Ahara-Vihar:

\begin{tabular}{|c|c|c|}
\hline Diseases & Pathya and Ahara & Apathya and Vihar \\
\hline PRAMEHA & $\begin{array}{l}\text { Langhan, vamana, virechana, udvartana, dipan } \\
\text { dravya, yava, shali, kulattha, mudga, tila, laja, } \\
\text { puransura, shigru, rason, gokshura, jambu, } \\
\text { trikatu, khadir, hasti and rukshadravya. }\end{array}$ & $\begin{array}{l}\text { Dhumapana, swedana, rakta mokshana, } \\
\text { divaswapna, masha, maithuna, } \\
\text { kushmandafala, } \\
\text { ikshurasa, madhur-amla-lavana } \\
\text { rasatmaka,abhishyandi } \\
\text { dadhisevana, navanna } \\
\text { sevana }\end{array}$ \\
\hline AAMVATA & $\begin{array}{l}\text { Rukshasweda, langhana, lepa, basti, virechana, } \\
\text { lepa, guduchi, puranashali, kulattha, purana } \\
\text { Madhya, takra, punarnava, eranda taila, rason, } \\
\text { shigru, karvellak, ushnajala, gokshura, } \\
\text { bhallataka, aardraka, katu- tikta } \\
\text { rasa dravya }\end{array}$ & $\begin{array}{l}\text { Dadhi, matsya, } r \text { guda, } \\
\text { dushitjala,vegasandharana, ratrijagarana, } \\
\text { aanoopmamsa evam abhishyandi padartha. }\end{array}$ \\
\hline MEDOROG & $\begin{array}{l}\text { Puranshali, mudga, kulattha,yava, } \\
\text { kodrava, lekhanabasti, chinta, } \\
\text { shrama,ratrijagarana,vyavaya,udvartana, } \\
\text { langhana,madhu, katu- tikta-Kashaya } \\
\text { rasatmakadravya,takra, madya,Triphala, } \\
\text { Guggulu,ushnajala, shuddhashilajatu, shigru, } \\
\text { pragbhojanavaripana. }\end{array}$ & $\begin{array}{l}\text { Shitalajala, kshira- } \\
\text { ikshuvikara,navinannapana, } \\
\text { masha, snehaabhyanga,divaswapna, } \\
\text { madhurabhojana, bhojanapaschatjalapana }\end{array}$ \\
\hline HRIDROGA & $\begin{array}{l}\text { Swedana,vamana,virechana,jangalamamsa, } \\
\text { mudgayusha,eranda taila, draksha, } \\
\text { takra,tambulabhakshana, madhu. }\end{array}$ & $\begin{array}{l}\text { Trushna-vamana-mutra- } \\
\text { apanavayushukradosha- } \\
\text { udgara-shramajaswasa-purisha- } \\
\text { ashruvegasandharana, aavikshira,ushna- } \\
\text { gurutikta- } \\
\text { amlapadarthasevana,rakta } \\
\text { mokshana,madhookpushpa and phala. }\end{array}$ \\
\hline ARSHA & $\begin{array}{l}\text { Leafy vegetables, surana, planty of water, fruit } \\
\text { andjuices, patola, bringel, beet root, carrot etc. }\end{array}$ & $\begin{array}{l}\text { Samshana, adhyashana, vishamashana, } \\
\text { avoid } \\
\text { tea and coffee, non veg, western toilets, } \\
\text { Alcohol, Urgency. }\end{array}$ \\
\hline Amlapitta & $\begin{array}{l}\text { Old shalidhanya rice, jou, mung, Dadim, } \\
\text { amla,madhu,karela,tikta rasa pradan ahar }\end{array}$ & $\begin{array}{l}\text { Naye anna,pitta prakopak } \\
\text { vihar,adharraniya vega } \\
\text { dahi,madya sevan }\end{array}$ \\
\hline
\end{tabular}

Dincharya and ritucharya according to Ayurveda and modern life style

The way in which a person lives is called lifestyle. In ancient times, people were following ideal Lifestyle. Therefore people were not much get affected by various types of diseases. Afterword, it has been turned into sedentary lifestyle. In modern era of civilization, due to growing use of technologies and increasing competition, changing lifestyle has become a leading cause for manifestation of many diseases like Diabetes mellitus, Obesity etc

Ayurveda explains life style under the heading of Dinacharya, Ratricharya, Ritucharya \& Sadvritta. These all things come under the Swasthavritta. Lifestyle includes our Ahara Vidhi, Vihara and Achara . In almost all samhitas, there is detail description of Dinacharya, Ratricharya, Ritucharya, Ahara Vidhi, Adharaniya and Dharaniya vega, Sadvritta etc. is given which are very helpful to an individual for healthy life and prevention of diseases. They are described on the basis of state of 'Doshas', and 'Agni' in human body according to the time and environmental factors. It is way for healthy life. Also the effects on body due to the changes done in this pattern are also stated. For example- Agnimandya.

Taking into consideration the importance of Lifestyle modification in the present era and also importance of the disease Agnimandya as it is a root cause for all other diseases and its causative factors are mostly related to lifestyle. 
Table 1:-List of Dinacharya and Rirucharya according to Ayurveda

\begin{tabular}{|l|l|}
\hline Dinacharya & Ritucharya \\
\hline Dantadhavana & Abhyanga \\
\hline Anjana & Udvartana \\
\hline Nasya & Dhumapana \\
\hline Kavala-Gandusha & Kavala \\
\hline Dhumapana & Gandusha \\
\hline Tambula Bhakshana & Anjana \\
\hline Abhyanga & Shayana \\
\hline Vyayama & Vastra Dharana \\
\hline Udvartana & Mani-malyadi Dharana \\
\hline Snana & Vyayama \\
\hline Mani-malyadi Dharana & Vyavaya \\
\hline Vastra dharana & Snana \\
\hline Karnapurana & \\
\hline Nidra & \\
\hline Vyavaya & \\
\hline Padatrana Dharana & \\
\hline Danda Dharana & \\
\hline
\end{tabular}

Life style in the ancient times was a little bit different than that of today. During that time, requirements of a person were minimum and faced less stress and strain. One could look after his health and could spend some time for keeping himself fit. The persons were following some specific measures, mentioned in the daily regimen like oil massage to the body, yoga, meditational practices, bathing, herbal smoking etc. In today's hectic and materialistic life, rarely people get time to think of their own health and fitness. Hence many people think that these entire daily regimens are impossible to follow. But it is the need of time to follow it by understanding its importance for the well being. One desirous of well being in this world and the world beyond should try his level best to follow the principles of health regarding to diet, conduct and action. One who persistently follows these prescriptions for the maintenance of positive health, gets devoid of all diseases, lives long life (hundred years) \& does not meet with an untimely death. One who follows Ritucharya vidhi according to Prakriti, never suffers from severe disorders caused by seasonal factors. One who resorts to wholesome diet and regimens, who enters into action after proper observation, who is unattached to the pleasure drawn from the satisfaction of sensory objects, who is given to charity, impartiality, truthfulness and forgiveness and who is at service of learned people, seldom gets affiicted with diseases. Acharya Charaka has given a guide line for being healthy as by the knowledge of the place,

\section{Pathogenesis of various life style disorder}

The people, who don't follow the proper principles about Ahara Vidhi, Vihara and Achara, suffer from various kinds of diseases especially of digestive system. Among which ,Agnimandya is very common. Agnimandya is the basic cause for pathogenesis of various diseases. In Ayurvedic classics faulty lifestyle like improper dietary habits, improper sleep pattern, stress etc. have been stated as main causative factors for its manifestation of Agnimandya. So, in preventive as well as curative aspect of Agnimandya and ultimately almost all diseases which are caused due to Agnimandya, lifestyle modification is very essential. By following the proper Ahara Vidhi, Vihara and Achara, it is possible to prevent and cure these diseases and regain a physically and psychologically changes.

Samprapti of Agnimandya: Due to excessive consumption of Vata Prakopaka Ahara Vihara, Pitta could not be got proper nourishment of Pitta and contraction of Srotas of Pachaka Pitta occurs. These all phenomenon creates vitiation of Pachaka Pitta, which leads to Agnimandya. Excessive consumption of Drava, Snigdha etc. diet vitiates Agni by increment of Drava, Snigdha etc. Guna of Pitta which leads to Jatharagnimandya.Increment of Shita, Snigdha, Manda Guna due to Kapha Prakopa opposes the Ushna, Tikshna Guna of Agni. Further vitiated Kapha covers the place of Pachaka Pitta and also dilutes it. All these factors make Agni-dushti that leads to Agnimandya. 


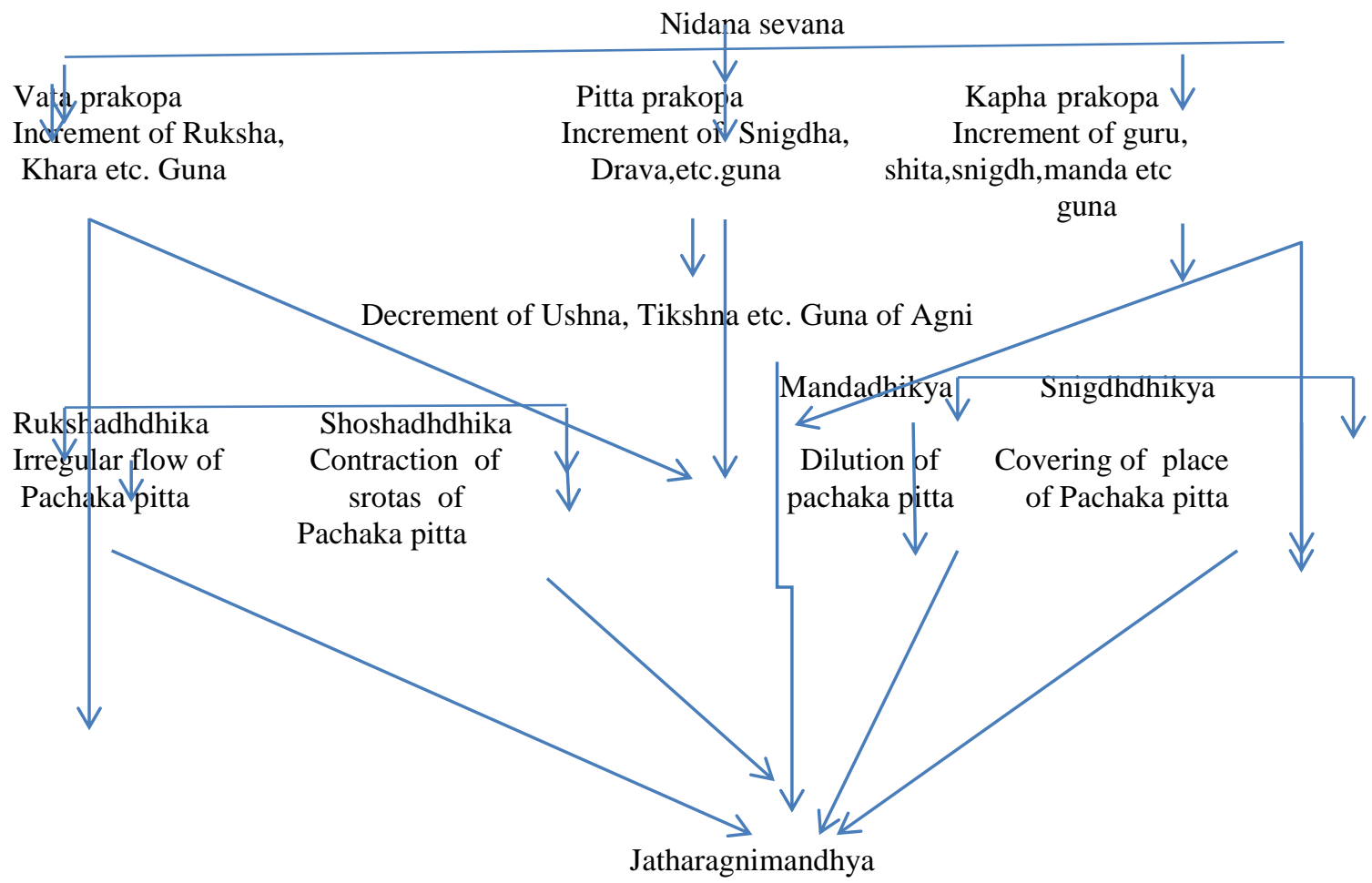

\section{Upadrava of Agnimandya:}

An Upadrava occurs as a sequel resulting from the main disease. The Upadrava of Agnimandya are mainly as: Ajirna: The vitiated Dosha which are involved in the development of Agnimandya leads to the manifestation of Ajirna, Ama. Ajirna being almost an inevitable sequence of Agnimandya, the Ama could also be regarded as a complication of Agnimandya as it is an immediate resultant of Ajirna.

Ama-Jatharagni is maintaining the formation of Dosha, Dhatu and Mala. Thus if there is Mandagni, intake will not fully transformed into end products and intermediate products will be produced. Such intermediate products or undigested products may comprehensively termed as Ama. Ama denotes a substance or group of substances which is near to poison or acts like a poison. Agnimandya and its resultant Ama play an important role in producing pathogenesis of many diseases. Ama can be formed even at the level of Doshagni, Bhutagni, Dhatvagni or Malagni. When this Ama or Apakva Rasa mix and radiate with Dosha, Dhatu and Mala it's called Sama. By the production of impairment in the micro and macro channels of the body it produces Srotovaigunya or the seat for the accumulation of the provoked Dosha, converting in the form of any disease. According to modern physiology a variety of transforming and transmitting substances are present in the body like enzymes, hormones, catalysts etc. When these are unable to function properly, different metabolites are formed which not acquired by the body. On further process these go on accumulate in different systems, affecting normal mechanism of the respective system. SadhyaAsadhyata:

It depends much on the will of the patient to co-operate with the instructions of the physician and it also upon the causative factors. If a patient is not able to change his diet and Lifestyle have strong causative factors makes Agnimandya Krichchhrasadhya. On the other hand, if the causative factor is weak and the patient is able to control his diet and also follow the prescribed treatment fully, the condition becomes Sadhya. Agnimandya as a root cause of all diseases: Wrong dietary habits like Adhyashana, Vishamashana and wrong behavioral pattern like Vegadharana which lead to vitiation of Tridoshas independently or together which result in manifestation of disease Agnimandya. In Ayurveda, it is believed that Agnimandya is root cause for all diseases like Prameha, Sthaulya etc.

\section{Conclusion:-}

So, every one should be aware about their lifestyle, By proper lifestyle we can improve the health status and longativity of life. One should take meal according to the main principles mentioned in our Ayurvedic literature i.e. ritucharya ,dincharya and Ahara Vidhividhana, in order to increase the longevity of life. Everybody should 
advocates dietary and life style management in case of derangements of Agni in any form. Significance of Agni has been seen in both the healthy (physiological) and diseased condition (pathological).In healthy condition it is necessary for maintenance of health while in diseased condition it is important for diagnosis as well as treatment of the particular disease.

\section{Refrences:-}

1. Sharma PV: Editor, Sushruta Samhita of Dalhana, Sutrasthana; Varanasi; Chaukhamba Vishvabharati, Oriental Publishers and Distributors, Ed. 1, 2010.

2. Charaka S, Sashtri Kashinath, Pt, Chaturvedi Gorakhnath., Chaukhamba Bharti Academy; 2004.

3. Charaka Samhita Part I Vaidyamanorama Hindi Commentary by Ravi Dutta Tripathi, Chaukhamba Sanskrit Pratishthan.

4. Upadhyaya Y: Madhava Nidanam, 1st part. Varanasi: Chaukhambha Publication, 2007, Amavatanidanadhaya.

5. Gupt Atridevgupt., Hridyam A: Varanasi: Chaukhambha prakkashan, 2009 publisher

6. Sharma PV: Editor, Sushruta Samhita of Dalhana, Sutrasthana; Anapanvidhi Adhyaya: Varanasi: Chaukhamba Vishvabharati, Oriental Publishers and Distributors, Vol. I, 2010: 561.

7. Vaidya Yadavaji Trikamji Acharya, Charak Samhita, Chakrapani Tika, Chaukhamba Prakashan, Reprint 2013 P.513.

8. shastri Ambikadutt: Editor,, Sutrasthana; Vranaprashna Adhyaya: Chapter 21 sutrasthan. Varanasi: Chaukhamba Vishvabharati, Oriental Publishers and Distributors, Ed. 1, Vol. I, 2010: 227.

9. Upadhyaya Y: Editor, Astangahrdaya of Vagbhata, Sutra Sthan; Dosabhedeeya Adhyaya: chapter 12, Verse 1213,Varanasi: Chaukhambha Prakashan, Ed. 1, 2007: 90-91.

10. Srivastava S: Editor, Sharngadhar Samhita of Acharya Sharngadhar, Varanasi: Chaukhambha Orientalia, Ed. 1, 2005: 41-42.

11. Sharma PV: Editor, Sushruta Samhita of Dalhana, Sutrasthana; Aturupkramneeya Adhyaya: Varanasi: Chaukhamba Vishvabharati, Oriental Publishers and Distributors, Ed. 1, Vol. I, 2010:334-3

12. Charaka S, Sashtri Kashinath, Pt, Chaturvedi Gorakhnath; Varanasi: Chaukhamba Bharti Academy; 2004. Chikitsasthana, ..

13. Ashtanga Hridaya, Edited by Dr. shailja shrivastav, Chaukhambha Surbharati Prakashan, Varanasi, Reprint Edition, 2002 Sutra Sthana.

14. charak samhita(first and second part)- Dr. Harishchandra Kushwaha.1st edition Chaukhambha orientellia, Varanasi ;2005

15. YogRatnakar- Vidyotini hindi tika,Bramhashankar shastri, chaukhamba Sanskrit series office,Varanasi.

16. Kashayap samhita- shri satyapal bhishakacharya, Vidyotini hindi vyakhya.9th edition chaukhamba Sanskrit series office, Varanasi.

17. shanrangdhar samhita- Dipika hindi vyakhaya, Dr.Bramhaannad Tripathi, chaukhamba surbharti prkasan,varansi;2001.

18. Bhav Prakash (purvardh and uttardha)- Bramhashankar shastri chaukhambha Sanskrit series office Varanasi

19. Madav nidan- Dr.Bramhaannad Tripathi, chaukhamba surbharti prkasan,varansi;2001. 